\title{
Synthetic seed production for germplasm storage of Hydrastis canadensis L. (Goldenseal)
}

\author{
Satyaprakash R. Settipalli \\ West Virginia University
}

Follow this and additional works at: https://researchrepository.wvu.edu/etd

\section{Recommended Citation}

Settipalli, Satyaprakash R., "Synthetic seed production for germplasm storage of Hydrastis canadensis L. (Goldenseal)" (2007). Graduate Theses, Dissertations, and Problem Reports. 2558.

https://researchrepository.wvu.edu/etd/2558

This Thesis is protected by copyright and/or related rights. It has been brought to you by the The Research Repository @ WVU with permission from the rights-holder(s). You are free to use this Thesis in any way that is permitted by the copyright and related rights legislation that applies to your use. For other uses you must obtain permission from the rights-holder(s) directly, unless additional rights are indicated by a Creative Commons license in the record and/ or on the work itself. This Thesis has been accepted for inclusion in WVU Graduate Theses, Dissertations, and Problem Reports collection by an authorized administrator of The Research Repository @ WVU. For more information, please contact researchrepository@mail.wvu.edu. 


\title{
Synthetic Seed Production for Germplasm Storage Of Hydrastis canadensis L. (Goldenseal)
}

\author{
Satyaprakash R. Settipalli \\ Thesis submitted to the \\ Davis College of Agriculture, Forestry and Consumer Sciences at \\ West Virginia University \\ in partial fulfillment of the requirements for the degree of \\ Master of Science \\ In \\ Horticulture
}

Todd P. West, Ph.D., Chair

Sven J. Verlinden, Ph.D

Deborah A Boone, Ph.D

Thomas R. McConnell

\section{Division of Plant and Soil Sciences}

Keywords: synseed, solid bead, hollow bead, alginate encapsulation, in vitro conservation, micro encapsulation 


\begin{abstract}
Synthetic Seed Production for Germplasm Conservation of Goldenseal (Hydrastis canadensis L.) Satyaprakash R Settipalli
\end{abstract}

Goldenseal (Hydrastis canadensis L.) is an important medicinal plant, native to Canada and Eastern United States, used as an antibiotic, anticonvulsant and in treatments for inflammations and dyspepsia. Over collection of wild population and native habitat destruction has lead the species to be listed as an endangered species in the Convention on International Trade in Endangered Species of Wild Fauna and Flora (CITES), Appendix II. This brought a revived interest in conservation of germplasm.

Calcium alginate solid and hollow bead encapsulation protocols were evaluated. Shoot and callus propagules were encapsulated in calcium alginate solid bead (supplemented with stage II nutrient media) and hollow bead (no nutrient supplements) and were stored at $25^{\circ} \mathrm{C}$ and $5^{\circ} \mathrm{C}$ for either 4,8 or 12 weeks. Best regeneration and viability were observed in $2.5 \%$ alginate concentrated solid shoot propagules that were stored at $5^{\circ} \mathrm{C}$. By the end of 6 weeks of sub culturing $100 \%$ regeneration was achieved. Reduced (10\%) regeneration was observed in callus propagules stored at $5^{\circ} \mathrm{C}$, and all the callus propagules stored at $25^{\circ} \mathrm{C}$ were necrotic. 
Shoot propagules encapsulated in hollow beads also shown good viability

percentage at $5^{\circ} \mathrm{C}$, however there was significant decline in regeneration with increased experimental storage time. 


\section{TABLE OF CONTENTS}

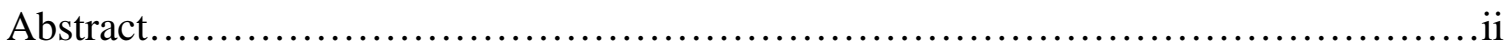

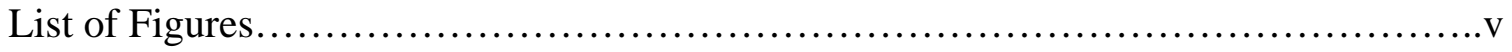

List of Tables.............................................................vi

List of Appendix Tables.......................................................vii

SYNTHETIC SEED PRODUCTION FOR GERMPLASM CONSERVATION OF GOLDENSEAL 1

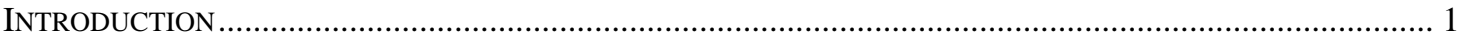

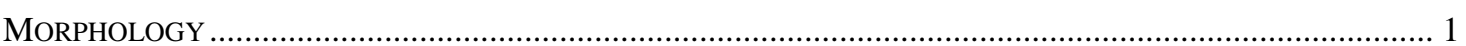

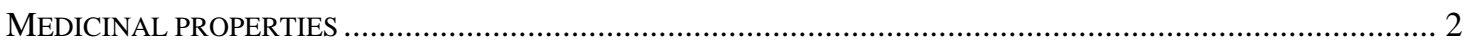

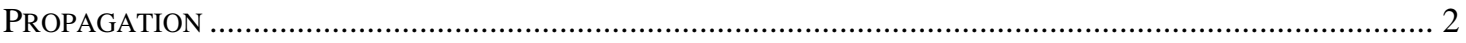

SYNTHETIC SEED PRODUCTION ................................................................................................... 3

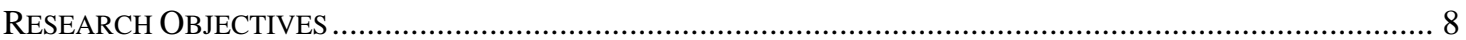

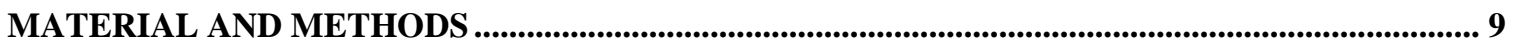

SOURCE OF EXPLANT MATERIAL FOR STAGE II SUBCULTURES ............................................................. 9

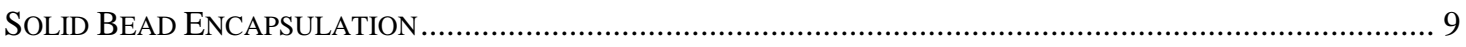

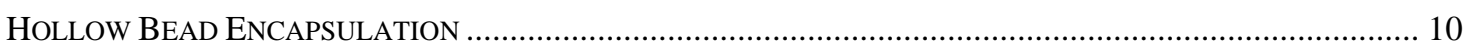

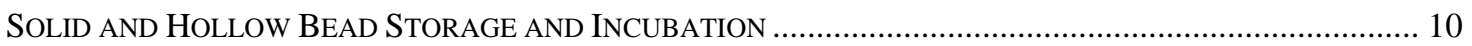

SOLID BEAD ENCAPSULATION AND PROPAGULE REgENERATION EXPERIMENT ........................................ 11

Hollow BeAd ENCAPSUlation AND PRopagules REgENERATION EXPERIMENT.................................. 11

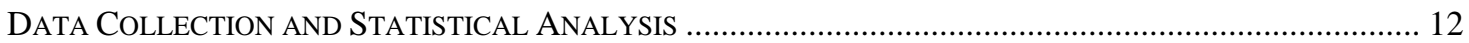

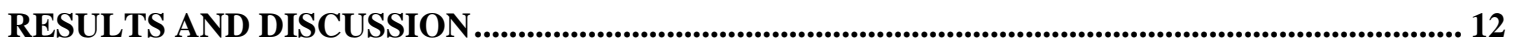

SOLID BEAD ENCAPSULATION AND PROPAGULE REgENERATION EXPERIMENT ........................................ 12

Solid Bead Encapsulated Callus Propagules....................................................................................... 13

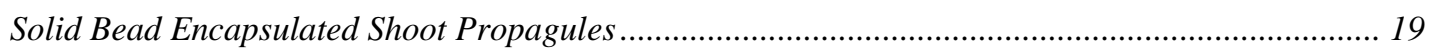

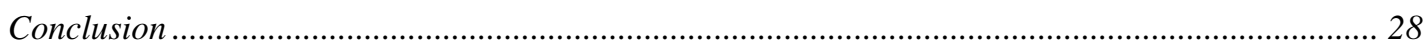

Hollow BEAd ENCAPSUlation AND PROPAGUle REgENERATION EXPERIMENT …............................... 31

Hollow Bead Encapsulated Callus Propagules ............................................................................... 31

Hollow Bead Encapsulated Shoot Propagules................................................................................... 34

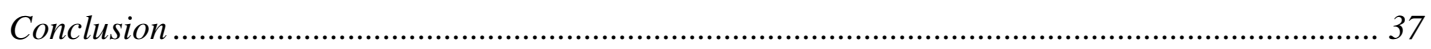

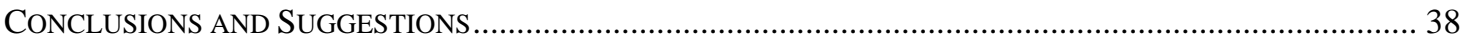

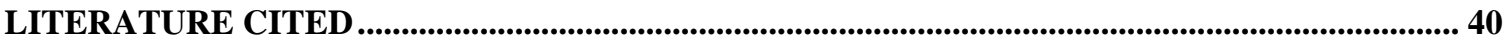

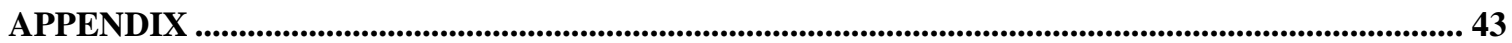




\section{List of Figures}

Figure 1: Comparison of encapsulated shoot propagules stored at $5^{\circ} \mathrm{C}$ and $25^{\circ} \mathrm{C}$ for 4 weeks.

Figure 2: Comparison of solid encapsulated shoot propagules stored at $5^{\circ} \mathrm{C}$ and $25^{\circ} \mathrm{C}$ for 8 weeks.

Figure 3: Comparison of solid encapsulated shoot propagules stored at $5^{\circ} \mathrm{C}$ and $25^{\circ} \mathrm{C}$ for 12 weeks.

Figure 4: Comparison of encapsulated shoot propagules at 4 weeks of sub culturing that were stored at $5^{\circ} \mathrm{C}$ and $25^{\circ} \mathrm{C}$ for 8 weeks

Figure 5: Growth rate of encapsulated shoot propagules stored at $5^{\circ} \mathrm{C}$ for 4,8 and 12 weeks at each sub culturing ....

Figure 6: Shrinkage of encapsulated solid beads at $5^{\circ} \mathrm{C}$ and $25^{\circ} \mathrm{C}$ after 12 weeks storage

Figure 7: Leaking of inner cushioning solution from hollow beads after 4 week storage at $5^{\circ} \mathrm{C}$ and $25^{\circ} \mathrm{C}$ 


\section{List of Tables}

Table 1: Effects of Storage Temperature and Storage Time on Callus Size and Viability of Encapsulated Callus Propagules after 6 weeks of Sub-culturing

Table 2: Mean Callus Size and Viability of Callus Propagules at Different Alginate Concentrations, Storage Temperature and Storage Time Combinations.

Table 3: Effects of Storage Temperature and Storage Time on Shoot Length and Viability of Encapsulated Shoot Propagules after 6 weeks of Sub-culturing

Table 4: Mean Shoot Length and Viability Percentage of Shoot Propagules Stored at Different Temperature and Storage Time Combinations.

Table 5: Effects of Storage Temperature and Storage Time on Shoot Length and Viability of Hollow Bead Encapsulated Shoot Propagules after 6 Weeks of Sub-culturing........... 35

Table 6: Mean Shoot Length and Viability Percentage of Hollow Bead Shoot Propagules Stored at $5^{\circ} \mathrm{C}$ and at different storage times. 36 


\section{List of Appendix Tables}

Appendix Table 1: Effect of storage temperature, storage time and alginate concentration on callus size of calcium alginate encapsulated callus propagules.

Appendix Table 2: Effect of storage temperature, storage time and alginate concentration on viability of calcium alginate encapsulated callus propagules

Appendix Table 3: Effect of storage temperature, storage time and alginate concentration on shoot length of calcium alginate encapsulated shoot propagules 45

Appendix Table 4: Effect of storage temperature, storage time and alginate concentration on viability of calcium alginate encapsulated shoot propagules

Appendix Table 5: Effect of storage temperature, storage time and alginate concentration on shoot length of calcium alginate hollow bead encapsulated shoot propagules.

Appendix Table 6: Effect of storage temperature, storage time and alginate concentration on viability of calcium alginate encapsulated shoot propagules...... 


\section{Synthetic Seed Production for Germplasm Conservation of Goldenseal}

\section{Introduction}

Goldenseal (Hydrastis canadensis L.) belongs to the family Ranunculaceae, known for its varied medicinal properties. Native to Canada and the Eastern United States, goldenseal is found naturally in the moist mountainous woodland areas.

Roots are bright yellow in color and thus are named goldenseal. It is also known as ground raspberry, orange root, and yellow root (Grieve, 1995). The part of the plant that is useful with medicinal properties is rhizome/root. Roots constitute Iso-quinoline alkaloids, mainly hydrastine, berberine, canadine, and lesser amounts of other alkaloids (Davis and McCoy, 2000).

\section{Morphology}

Goldenseal is an herbaceous perennial that grows up to 12 inches tall. Its stem is bright yellow in color below the ground and purplish above the ground, forked with two terminal 5-7 lobed palmate leaves. Its roots are bright yellow in color and modified as rhizomes with numerous fibrous rootlets. It generally matures in 4-5 years. Roots are harvested in fall after the fruit has ripened. Then they are dried and used for commercial trading. The plant blooms from April - May, each bloom is $1 / 2$ inch in diameter with 3 small petal-like sepals; its flowers are hermaphrodite (both sexes on same flower). Self and cross pollination is seen. Its fruit is a berry and ripens during July - August. 


\section{Medicinal properties}

Native American Tribes such as the Cherokee used the root for inflammations and as treatment for dyspepsia, cancer, whooping cough, diarrhea, tuberculosis, pneumonia and heart trouble (Davis and McCoy, 2000). Historically, it’s been used as eyewash, a bitter tonic, a digestive and appetite stimulant, and also as a treatment for mucus membrane inflammations (Faster 1991). Presently, it is used as an antibiotic, anticonvulsant, tonic, sedative, and for treatments of various inflammations (Predny and Chamberlain, 2005).

The varied medicinal properties of the reportedly useful plant, along with the myth that goldenseal can mask illicit drugs like morphine in urine tests, contributed to excessive collection of the plant (Predny and Chamberlain., 2005). This caused a serious reduction in the native population and placed the species on Appendix II of the Convention for International Trade and Endangered Species of Wild Fauna and Flora (Hall and Camper 2002, Davis and McCoy 2000, Bannerman 1997). The accelerating loss of population as a result of over-harvesting and native habitat destruction has yielded a revived interest in the propagation and conservation of the species.

\section{Propagation}

Goldenseal reproduces both sexually and asexually. Bulgy, knot-like buds that develop on rhizomes produce fibrous roots that eventually develop into independent plants. Goldenseal bears a single berry consisting of 20-30 seeds that are disseminated by wind and animals (Faster, 1991). However, plants propagated by either of these methods have limitations specifically related to germplasm storage. Seed-grown plants lack 
genetic uniformity because of higher genetic variations from heterozygosity (genetic variability among individuals within populations and variability among populations) (Kyte and Kleyn, 1996), and seedlings can take 5-9 years to attain maturity. Rhizome cuttings are genetically identical, but as the species itself are listed on endangered category, cuttings may not be readily available, or there may not be sufficient room for stock plants. These limitations may be overcome with the use of micro propagation techniques. Different researchers developed various micro propagation protocols using young leaves (Bedir et al., 2003), embryos (Hall and Camper, 2001), roots and shoots (Chun-Zhao et al., 2003) as explants to develop mass number of propagules of Goldenseal.

\section{Synthetic Seed Production}

Higher rates of cross pollination in goldenseal leads to variations and there is every chance of mixing of genes and loss of original germplasm which may in turn lead to genetic diversity (Hamrick et al., 2004). Germplasm conservation is important to conserve diverse genetic resources. Oldfield (1984) states that “conserved genetic resources are valued for hidden potential for enhancing the quality of life for present and future generations”. Seed storage and storage of parental stock plants are typically the two conventional methods followed for germplasm storage (Hartmann et al., 2002). However, both methods require large facilities and storage; seeds need to be stored in specialized facilities, and parental stock plants require either field or greenhouse space. Rhizome cuttings may be planted under protected environment at its native habitat. But it is more laborious and continuous monitoring for pest, disease and natural calamities like 
storms, forest fires is more difficult and the chance of loosing the germplasm because of above causes is high. In vitro propagation is also a method of germplasm conservation and the germplasm may be conserved through continuous regeneration cycles. However, continuous in vitro regenerations many times lead to somaclonal variations, genotypic or phenotypic variations that occur due to chromosomal rearrangement in the plant cells, commonly seen in plants regenerated from callus/ tissue culture, altering genetic variability (Scowcroft and Larkin, 1981). Somaclonal variation potential can be reduced utilizing in-vitro propagated germplasm, either by reducing the growth rate of the plantlet or by inhibiting growth completely (Collin and Edwards, 1998). One such method for reducing plantlet growth rates is alginate encapsulation which encapsulates the propagule in matrix and storing at low temperatures. Potentially, somaclonal variations may be reduced through alginate encapsulation as numbers of regenerations are reduced over a period of time.

Alginate encapsulation is a storage method that involves placing a plant propagule (somatic embryo or vegetative propagule such as shoot tips, nodal segments or callus) in a matrix that coats the propagule; this can improve the success of the transportation of aseptic plant material and germplasm storage (Piccioni and Standardi, 1995). Alginate naturally occurs as metallic salts of alginic acid in the form of either an alkali (Na or K) or alkaline salt (organic) complexes, which are soluble in water (Chapman and Chapman 1980).

Typically, sodium alginate is used for the encapsulation matrix. The matrix can simulate the endosperm by supplementing the required mineral components (macro and micro nutrients, vitamins, amino acids and carbohydrates) through incorporation in the 
encapsulation medium (Standardi and Piccioni, 1998). Plant growth regulators, pesticides, and fungicides can also be supplied to the plant propagule within the encapsulation medium (Bapat and Rao, 1990; Standardi and Piccioni, 1998).

The encapsulated embryonic and non-embryonic in-vitro derived explants or propagules can be stored at different conditions (Bapat and Rao, 1990; Piccioni and Standardi, 1995). An encapsulated propagule is called synthetic seed (synseed) or artificial seed. Encapsulation technique is also found to be promising for cryopreservation, plant genetic resources and germplasm conservation (Gardi et al., 1999; Mix-Wagner et al., 2003).

Aqueous solutions of alginate are strongly viscous, even at $1 \%$ solute concentration (Chapman and Chapman, 1980). By adding calcium to an aqueous solution of sodium alginate the solution changes to a semi solid state by forming the calcium salt of alginate (calcium alginate). Sodium alginate is available in three different viscosities, low (250 centa poise (cp)), medium (350 cp) and high (14,000 cp) for $2 \%$ solution at $25^{\circ} \mathrm{C}$ (Sigma - Aldrich). Generally low viscosity alginate is used for protoplasts and somatic embryo encapsulation (Castillo et al., 1998). Medium and high viscosity alginate is used for non-embryonic encapsulation (Piccioni and Standardi, 1995; Gardi et al., 1999). Most of the non embryonic studies report using alginate concentrations range from 1 to 3\%. Gardi et al. (1999) reported using 2.5\% sodium alginate while Piccioni et al. (1995) reported using 2.0\% for encapsulating woody species. Ballester et al. (1997) reported using 3.0\% for encapsulating shoot tips of Camellia.

Encapsulation medium, incorporated with stage II media (shoot proliferation medium formulation) components like mineral nutrients, growth regulators and sucrose 
increased ex-plant survival and subsequent shoot growth (Timbert et al., 1998; Ballester et al., 1997; Gardi et al., 1999). Use of these stage II media components in encapsulation significantly increased survival from 55.9 to $91.6 \%$ when compare to using alginate alone.

There are two main types or methods of alginate encapsulation, solid and hollow bead. Solid bead alginate encapsulation consists of a semi-solidified inner and solidified outer core which gives the propagule more protection and inhibits the growth of propagule (Patel et al., 2000). Hollow bead alginate encapsulation consists of a liquid inner core and solidified outer core offers protection as well as continued limited growth of explants within the bead (Patel et al., 2000). However, each alginate encapsulation method has certain limitations. Solid bead alginate encapsulated propagules have the tendency to protrude out of the solidified encapsulation medium reducing the protection of the propagule (Ganapathi et al., 1992). Hollow bead alginate encapsulation production protocol is time consuming and thickness of the bead is varied (Nyende et al., 2003). Success of encapsulation was also varied among the species and type of encapsulation used. Hollow beads were more successful than solid bead encapsulation in Potato (Nyende et al., 2003). The stage of the propagule is also important for success or failure of alginate encapsulated nodal segments of Hibiscus sp (West et al., 2006) and callus in carrots and potatoes (Patel et al., 2000).

Encapsulated propagules can be stored at different temperatures. Lower temperatures inhibit the growth of encapsulated propagules; at $4^{\circ} \mathrm{C}$ encapsulated potato shoot tips slowed down the metabolic rates with high viability and long term storability than at $10^{\circ} \mathrm{C}$ (Nyende et al., 2003). 
The purpose of these study was to develop an encapsulation protocol by evaluating the appropriate alginate concentrations, bead storage time and storage temperatures. Currently, there are no reports on using alginate encapsulation (solid or hollow bead) and short term storage of Hydrastis Canadensis propagules for synseed production. 


\section{Research Objectives}

I. Evaluation of synthetic seed production for germplasm storage of Goldenseal.

1. To evaluate the encapsulation protocol for solid and hollow bead encapsulation.

2. To determine the effects of storage time (4, 8, and 12 weeks) utilizing solid and hollow bead encapsulation for germplasm storage.

3. To determine the effective propagule source (callus and shoot) for encapsulation and germplasm storage.

4. To determine the effect of storage temperature $\left(5\right.$ and $25^{\circ} \mathrm{C}$ ) on encapsulation for germplasm storage.

II. To evaluate the re-introduction of synthetic seeds to growth media in vitro to determine the effects of storage on plant tissue regeneration. 
Material and Methods

Source of Explant Material for Stage II Subcultures

Roots collected from the WVU Agronomy farm were grown in $2.5 \mathrm{~L}$ pots inside the WVU Davis College of Agriculture Greenhouse, under natural light conditions. Plants were irrigated by hand watering to avoid direct moisture from coming in contact with leaf material which subsequently reduces microbial contamination of leaf explants. Young leaf discs from these greenhouse-grown Hydrastis canadensis were used for initiating callus cultures using the methods described by Bedir et al., (2004).

\section{Solid Bead Encapsulation}

2, 2.5 and 3\% viscous solutions of sodium alginate, $250 \mathrm{ml}$ each were prepared (by mixing 5, 6.5 and 7 grams of sodium salt of alginic acid ${ }^{1}$ in $250 \mathrm{ml}$ of double distilled water and autoclaved for 23 minutes to ensure complete sterilization), supplemented with the nutrient salt solution as described by Bedir et al., (2004) for callus culture initiation of Hydrastis canadensis leaf discs. Calli and shoot forming propagules were excised from the in-vitro derived leaf derived calli with an approximate size of $5 \pm 1 \mathrm{~mm}$ in length. These propagules were coated with 2, 2.5 and $3 \%$ sodium alginate solutions aseptically and were dropped into a liter of stirring $50 \mu \mathrm{M} \mathrm{CaCl}_{2}$ solution using a sterile $10 \mathrm{ml}$ disposable pipette cap with one end cut making an aperture of $0.7 \mathrm{~mm}$ diameters. After 30 minutes of interlocking the excess $\mathrm{CaCl}_{2}$ solution was drained off and the coated beads were rinsed 3 times with sterile deionized distilled water $\left(\mathrm{ddH}_{2} 0\right)$.

\footnotetext{
${ }^{1}$ Product Number A-7128 purchased from Sigma-Aldrich Company, St. Louis, MO, 63178, USA
} 


\section{Hollow Bead Encapsulation}

Stage II leaf derived calli and shoot propagules with an approximate size of $5 \pm 1 \mathrm{~mm}$ were collected from sub culturing. $0.8 \%$ viscous sodium alginate solution was prepared using $8 \mathrm{~g}$ of sodium alginate in $1 \mathrm{~L}$ of $\mathrm{ddH}_{2} \mathrm{O}$. Interlocking and cushioning solution was prepared with $1 \%$ sterile $\mathrm{CaCl}_{2}$ solution and $1.5 \%$ carboxy methyl cellulose $^{1}$ (CMC). Excised callus and propagules were mixed in 40-50 ml of cushioning solution and dropped in to the stirring $0.8 \%$ sodium alginate solution using a sterile pipette with one end cut making an aperture of $0.7 \mathrm{~mm}$ diameters. After 15 minutes the excess sodium alginate solution was decanted, and the beads were thoroughly washed with sterile water to avoid sticking of beads. Following the decanting of excess sodium alginate solution, $250 \mathrm{ml}$ of $1 \%$ calcium chloride solution was pored on the beads for interlocking from outside to inside. After 20 minutes, excessive $\mathrm{CaCl}_{2}$ solution was decanted, and the beads were washed with sterile $\mathrm{ddH}_{2} \mathrm{O}$.

\section{Solid and Hollow Bead Storage and Incubation}

Encapsulated solid and hollow beads removed from the final rinse and placed in 100x15 mm disposable polystyrene petri dishes, with the edges wrapped in Parafilm ${ }^{2}$ to maintain high humidity conditions. These petri dishes containing propagules were stored separately at two different temperatures, $5^{\circ} \mathrm{C}$ and $25^{\circ} \mathrm{C}$ in dark for 4,8 and 12 weeks.

At every 4 weeks of storage propagules were removed from storage and placed on Stage II multiplication media using methods described by Bedir et al., (2004).

\footnotetext{
${ }^{1}$ Product Number C4888 Medium Viscosity, Purchased from Sigma Aldrich Company, St. Louis, MO, 63178, USA

${ }^{2}$ Parafilm “ $M$ ” ${ }^{\circledR}$, Pechiney Plastic Packaging, Chicago, IL, 60631, USA
} 


\section{Solid Bead Encapsulation and Propagule Regeneration Experiment}

The purpose of this study was to develop solid bead encapsulation protocol by evaluating the appropriate ex-plant source, alginate concentration, storage time, storage temperature and determine their effects on tissue regeneration when the propagules reintroduced to growth media. The three treatments; alginate concentration, storage time and storage temperature were combined in a $3 \times 3 \times 2$ factorial combination in this experiment.

Encapsulated shoot and callus propagules were collected from 4, 8 and 12 weeks of storage and incubated on stage II growth media (shoot multiplication MS media containing organics, phosphates, nitrates, iron, calcium, sulphates and sugars) using methods described by Bedir et al. (2004). At every 2 weeks of incubation the propagules were transferred to the fresh media and data on shoot length and viability were collected. Data were collected separately for two explant sources; callus and shoot, as each of type shows different growth levels. Callus size and viability data for encapsulated callus propagules and shoot length and viability data for encapsulated shoot propagules were collected. Data were collected for a total of 6 weeks and analyzed.

\section{Hollow Bead Encapsulation and Propagules Regeneration Experiment}

The focus of this experiment was to establish an appropriate hollow bead encapsulation protocol by evaluating ex-plant source, storage temperature, storage time and determine their combination effects on tissue regeneration. The two treatments; storage temperature and storage time were combined in a $2 \times 2$ factorial combination for each explant source and their effects on shoot length and viability were analyzed. 
Encapsulated propagules were collected from storage and incubated as described previously. Data were collected and analyzed on callus size or shoot length and viability, separately for callus and shoot. The propagules that were alive after storage were considered as survived and the propagules that started growing upon reintroduction on to the stage II media were considered as viable. However all the survived and viable beads were taken under viability for data analysis.

\section{Data Collection and Statistical Analysis}

All the experiments were arranged in a completely randomized design (CRD) and were conducted twice (two runs). All data were analyzed using analysis of variance (ANOVA) using General linear model (GLM) of SAS (SAS Institute, Inc., 2007). Data columns having $50 \%$ or more zeros were normalized using a square root transformation $(y+0.5)^{0.5}$ (Steel and Torrie, 1980). Shoot length and viability data of all the shoot and callus were counted and used for data analysis.

Results and Discussion

\section{Solid Bead Encapsulation and Propagule Regeneration Experiment}

Mean callus size or shoot length and viability at different alginate concentrations (2.0, 2.5 and $3.0 \%)$, storage temperatures $\left(5^{\circ} \mathrm{C}\right.$ and $\left.25^{\circ} \mathrm{C}\right)$ and storage times $(4,8$, and 12 weeks) were compared to determine the best treatment for encapsulation of Goldenseal callus and shoot propagules. 
Solid Bead Encapsulated Callus Propagules

As the experiments were conducted twice; mean callus size and viability were compared for two runs and there was no significant difference between the two experimental runs (Appendix 1, 2).

The 2-way and 3-way interaction of alginate concentration, storage temperature, and storage time had a significant effect on mean callus size. Mean callus size and viability were significantly different at different storage temperature, storage time and alginate concentration combinations (Appendix 1, Table 1).

Callus propagules stored at $5^{\circ} \mathrm{C}$ have shown significantly more callus growth than the propagules that were stored at $25^{\circ} \mathrm{C}$ (Table 1). All (100\%) of the solid encapsulated calli beads survived after 4 weeks of storage in dark at $5^{\circ} \mathrm{C}$, regardless of the alginate concentration, contrasting $60 \%$ survival of 4 weeks stored beads at $25^{\circ} \mathrm{C}$.

Surviving beads were clear and a large portion of the encapsulated callus shown black structures with small green tips on one side, no growth was seen. Patel et al. (2000) reported that Calli encapsulated in calcium alginate beads exhibited poor growth and dark structures were also seen on the grown Calli. These black structures suggest that conditions were not optimum for maintaining normal cellular function which resulted in necrosis. With increase storage time, explant survival was greatly reduced. All of the calli beads stored at $25^{\circ} \mathrm{C}$ for 8 and 12 weeks were necrotic with $0 \%$ viability.

At higher temperatures which are optimum for plant growth, the encapsulated callus beads would have continued physiological processes and not inhibiting growth and development. Callus culture mortality may be a result of decreased supplemental nutrient 
Table 1: Effects of Storage Temperature and Storage Time on Callus Size and Viability of Encapsulated Callus Propagules after 6 weeks of Sub-culturing

\begin{tabular}{|c|c|c|c|c|c|}
\hline $\begin{array}{c}\text { Storage } \\
\text { Temperature } \\
\left({ }^{\circ} \mathrm{C}\right)\end{array}$ & $\begin{array}{l}\text { Storage } \\
\text { Time } \\
\text { (Weeks) }\end{array}$ & $\begin{array}{c}\text { Alginate } \\
\text { Concentration } \\
(\%)\end{array}$ & $\begin{array}{l}\text { Number of } \\
\text { Callus } \\
\text { propagules }\end{array}$ & $\begin{array}{l}\text { Mean Callus } \\
\text { Size }(\mathrm{cm})^{1}\end{array}$ & $\begin{array}{c}\text { Survival } \\
\text { (\%) }\end{array}$ \\
\hline \multirow[t]{9}{*}{5} & 4 & 2 & 40 & $0.35250 \mathrm{~A}$ & 10 \\
\hline & & 2.5 & 40 & $0.36750 \mathrm{~A}$ & 10 \\
\hline & & 3 & 40 & $0.31500 \mathrm{AB}$ & 10 \\
\hline & 8 & 2 & 40 & $0.23250 \mathrm{ABC}$ & 0 \\
\hline & & 2.5 & 40 & $0.23250 \mathrm{ABC}$ & 0 \\
\hline & & 3 & 40 & $0.08500 \mathrm{CD}$ & 0 \\
\hline & 12 & 2 & 40 & $0.00000 \mathrm{D}$ & 0 \\
\hline & & 2.5 & 40 & $0.00000 \mathrm{D}$ & 0 \\
\hline & & 3 & 40 & $0.00000 \mathrm{D}$ & 0 \\
\hline \multirow{9}{*}{25} & 4 & 2 & 40 & $0.01250 \mathrm{D}$ & 0 \\
\hline & & 2.5 & 40 & $0.22250 \mathrm{BC}$ & 0 \\
\hline & & 3 & 40 & $0.14750 \mathrm{BCD}$ & 0 \\
\hline & 8 & 2 & 40 & $0.00000 \mathrm{D}$ & 0 \\
\hline & & 2.5 & 40 & $0.00000 \mathrm{D}$ & 0 \\
\hline & & 3 & 40 & $0.00000 \mathrm{D}$ & 0 \\
\hline & 12 & 2 & 40 & $0.00000 \mathrm{D}$ & 0 \\
\hline & & 2.5 & 40 & $0.00000 \mathrm{D}$ & 0 \\
\hline & & 3 & 40 & $0.00000 \mathrm{D}$ & 0 \\
\hline Significance $^{2}$ & - & - & - & $* *$ & $* *$ \\
\hline
\end{tabular}

\footnotetext{
${ }^{1}$ Bonferroni (Dunn) t Test for paired comparisons

${ }^{2}$ ns, *, ** Non significant, significant at 5 and $1 \%$ level, respectively according to $F$ test
} 
salts, depleted available sugars because of continued explant cellular respiration or from exposure to the alginate matrix (alginate toxicity). Embryonic Calli of Daucus carota cultured without supplemental nutrient salts turned brown after 3 days and the growth was arrested (Lee et al., 2001). Alginate toxicity was seen in endangered orchid spp. resulting in poor regeneration (Redenbaugh, 1987).

Upon reintroduction of the viable callus beads onto stage II multiplication media, only $10 \%$ of propagules that were stored for 4 weeks at $5^{\circ} \mathrm{C}$ shown callus growth by the end of 6 weeks of sub culturing. All the other callus propagules were necrotic. Decline in regeneration frequency in encapsulated propagules may be a result of inhibited respiration of plant tissues by alginate and accumulation of metabolic wastes in the alginate capsule under poor ventilation conditions (Redenbaugh et al., 1987). By the end of 6 weeks of sub culturing only $10 \%$ of the beads that were stored for 4 weeks were alive with no adventitious shoot differentiation occurring. Mean callus size and viability of callus propagules at different storage temperature, storage time and alginate concentration interactions at each sub culturing are shown in Table 2.

Alginate concentration had a significant effect on mean callus height. More callus growth was observed at 2.0 and 2.5\% alginate concentrations than at 3\% (Table 1). High concentrations (3\%) of high viscosity sodium alginate were found to be very difficult to work with. High concentrations were difficult to dissolve in to solution and coat the propagule. While as low concentration (2\%) was very fluid and had poor coating capabilities as a result of low viscosity. In this experiment highest callus growth was observed at 2.5\% and lowest at 3\%. Physical barrier of hard matrix at 3\% concentration 
Table 2: Mean Callus Size and Viability of Callus Propagules at Different Alginate Concentrations, Storage Temperature and Storage Time Combinations.

\begin{tabular}{|c|c|c|c|c|c|}
\hline $\begin{array}{c}\text { Storage } \\
\text { Temperature } \\
\left({ }^{\circ} \mathrm{C}\right)\end{array}$ & $\begin{array}{l}\text { Storage } \\
\text { Time } \\
\text { (Weeks) }\end{array}$ & $\begin{array}{c}\text { Alginate } \\
\text { Concentration } \\
(\%)\end{array}$ & $\begin{array}{c}\text { Week } \\
\text { Data taken }\end{array}$ & $\begin{array}{l}\text { Mean } \\
\text { Callus Size } \\
(\mathrm{cm})\end{array}$ & Survival \% \\
\hline \multirow[t]{38}{*}{5} & 4 & 2 & 0 & 0.50 & 100 \\
\hline & & & 2 & 0.70 & 60 \\
\hline & & & 4 & 1.06 & 30 \\
\hline & & & 6 & 1.70 & 10 \\
\hline & & 2.5 & 0 & 0.50 & 100 \\
\hline & & & 2 & 0.64 & 70 \\
\hline & & & 4 & 0.90 & 40 \\
\hline & & & 6 & 1.50 & 10 \\
\hline & & 3 & 0 & 0.50 & 100 \\
\hline & & & 2 & 0.55 & 80 \\
\hline & & & 4 & 0.66 & 30 \\
\hline & & & 6 & 1.2 & 10 \\
\hline & 8 & 2 & 0 & 0.50 & 60 \\
\hline & & & 2 & 0.66 & 60 \\
\hline & & & 4 & 0.70 & 40 \\
\hline & & & 6 & 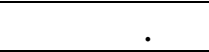 & 0 \\
\hline & & 2.5 & 0 & 0.50 & 60 \\
\hline & & & 2 & 0.75 & 60 \\
\hline & & & 4 & 0.90 & 20 \\
\hline & & & 6 & & 0 \\
\hline & & 3 & 0 & 0.5 & 20 \\
\hline & & & 2 & 0.6 & 20 \\
\hline & & & 4 & 1.2 & 10 \\
\hline & & & 6 & . & 0 \\
\hline & 12 & 2 & 0 & . & 0 \\
\hline & & & 2 & . & 0 \\
\hline & & & 4 & . & 0 \\
\hline & & & 6 & . & 0 \\
\hline & & 2.5 & 0 & . & 0 \\
\hline & & & 2 & . & 0 \\
\hline & & & 4 & $\cdot$ & 0 \\
\hline & & & 6 & . & 0 \\
\hline & & 3 & 0 & . & 0 \\
\hline & & & 2 & . & 0 \\
\hline & & & 4 & . & 0 \\
\hline & & & 6 & . & 0 \\
\hline & & & & & \\
\hline & & & & & Cont.... \\
\hline
\end{tabular}




\begin{tabular}{|c|c|c|c|c|c|}
\hline & & & & & \\
\hline \multirow[t]{37}{*}{25} & 4 & 2 & 0 & 0.50 & 10 \\
\hline & & & 2 & 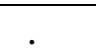 & 0 \\
\hline & & & 4 & . & 0 \\
\hline & & & 6 & & 0 \\
\hline & & 2.5 & 0 & 0.50 & 90 \\
\hline & & & 2 & 0.62 & 70 \\
\hline & & & 4 & . & 0 \\
\hline & & & 6 & & 0 \\
\hline & & 3 & 0 & 0.51 & 80 \\
\hline & & & 2 & 0.60 & 30 \\
\hline & & & 4 &. & 0 \\
\hline & & & 6 & . & 0 \\
\hline & 8 & 2 & 0 & . & 0 \\
\hline & & & 2 & . & 0 \\
\hline & & & 4 & . & 0 \\
\hline & & & 6 & . & 0 \\
\hline & & 2.5 & 0 & . & 0 \\
\hline & & & 2 & . & 0 \\
\hline & & & 4 & . & 0 \\
\hline & & & 6 & . & 0 \\
\hline & & 3 & 0 & . & 0 \\
\hline & & & 2 & . & 0 \\
\hline & & & 4 & . & 0 \\
\hline & & & 6 & . & 0 \\
\hline & 12 & 2 & 0 & . & 0 \\
\hline & & & 2 & . & 0 \\
\hline & & & 4 & . & 0 \\
\hline & & & 6 & . & 0 \\
\hline & & 2.5 & 0 & $\dot{\square}$ & 0 \\
\hline & & & 2 & . & 0 \\
\hline & & & 4 & . & 0 \\
\hline & & & 6 & - & 0 \\
\hline & & 3 & 0 & . & 0 \\
\hline & & & 2 & . & 0 \\
\hline & & & 4 & . & 0 \\
\hline & & & 6 & . & 0 \\
\hline & & & & & \\
\hline
\end{tabular}


that inhibited the growth of callus or higher concentrations of sodium present at high alginate concentrations that reduces plant nutrient uptake might be the possible reasons for poor growth at 3\%. Timbert et al. (1995) reported that the increased bead density at high alginate concentrations have increased the pressure and had a negative effect on germination of carrot somatic embryos.

Some encapsulated callus propagules shown sign of viability; however they became necrotic in the capsule before they broke out of encapsulated matrix. Depletion of supplemental nutrients salts and shear forces of the high viscosity alginate matrix on the propagules may have been the cause of the necrosis. Encapsulated Olea spp.propagules shown $46-100 \%$ viability after 30 days storage but least regeneration probably because of inadequacy of supplemental nutrient salts (Gardi et al., 1999). Rupturing the beads or excising the propagules from the bead after termed storage and prior to transferring onto the media, may increase the viability and chance of regeneration, as the nutrients are readily available and the shear forces of encapsulated matrix are avoided.

In this experiment the $2.5 \%$ concentrated encapsulated callus beads that were stored at $5{ }^{\circ} \mathrm{C}$ for 4 weeks have shown high viability at 0 weeks of sub culturing however the regeneration of the stored callus reduced over time as a result of extended storage time. By the end of 6 weeks of sub culturing only $10 \%$ of the callus beads that were stored for 4 weeks were viable with no adventitious shoot differentiation. None of the callus propagules shown shoot or root differentiation by the end of 6 weeks of sub culturing.

This data suggests that solid encapsulation of callus propagules is not a suitable protocol for long term germplasm conservation. There are few reports of utilizing 
encapsulation of callus propagules, however no reports were found on long term storage of Goldenseal callus.

Solid Bead Encapsulated Shoot Propagules

Alginate concentration did not have a significant effect on shoot length from encapsulated shoot propagules (Appendix 3, Table 3). One-way and two-way interactions of storage temperature and storage time had a highly significant effect on mean shoot length. Mean shoot length of shoot propagules that were stored for 4 weeks at $5^{\circ} \mathrm{C}$ were not significantly different with shoot propagules that were stored at $25^{\circ} \mathrm{C}$. However the viability was significantly reduced.

After 6 weeks of sub culturing the shoot propagules that were stored at $5^{\circ} \mathrm{C}$ shown $90 \%$ viability contrast with 33\% viability of shoot propagules that were stored at $25^{\circ} \mathrm{C}$ for 4 weeks (Appendix 4, Table3).

Mean shoot length of shoot propagules that were stored at $5^{\circ} \mathrm{C}$ for 4,8 and 12 weeks was not significantly different with shoot length of propagules stored at $25^{\circ} \mathrm{C}$ for 4 weeks, as a result of etiolated shoots produced by shoot propagules stored for 4 weeks at $25^{\circ} \mathrm{C}$ (Figure 1). All the encapsulated shoot propagules stored at room temperatures $\left(25^{\circ} \mathrm{C}\right)$ for 4,8 and 12 week periods elongated and broke out of the bead. Shoots that came out of the 4 week stored beads were etiolated with long and yellowish shoots, with $100 \%$ survival. Even though $100 \%$ of the beads that were stored for 8 weeks were germinated in storage, only 76\% (23 out of 30) survived by the end of the storage period (Table 4). Shoots were more etiolated with necrotic spots as seen in Figure 2. Also all the shoots that were stored for 12 weeks elongated in storage with only $33 \%$ survival but were nearly $50 \%$ desiccated from the shoot apex as seen in Figure 3 . The average shoot 
Table 3: Effects of Storage Temperature and Storage Time on Shoot Length and Viability

\begin{tabular}{|c|c|c|c|c|}
\hline $\begin{array}{c}\text { Storage } \\
\text { Temperature } \\
\left({ }^{\circ} \mathrm{C}\right)\end{array}$ & $\begin{array}{c}\text { Storage Time } \\
\text { (Weeks) }\end{array}$ & $\begin{array}{c}\text { Number of } \\
\text { Shoot } \\
\text { propagules }\end{array}$ & $\begin{array}{c}\text { Mean Shoot } \\
\text { Length }(\mathrm{cm})^{1}\end{array}$ & Survival (\%) \\
\hline 5 & 4 & 120 & $1.15083 \mathrm{~A}$ & 95 \\
\hline & 8 & 120 & $1.33917 \mathrm{~A}$ & 100 \\
\hline & 12 & 120 & $1.30250 \mathrm{~A}$ & 100 \\
\hline 25 & 4 & 120 & $1.13917 \mathrm{~A}$ & 70 \\
\hline & 8 & 120 & $0.55167 \mathrm{~B}$ & 36 \\
\hline & 12 & 120 & $0.08250 \mathrm{C}$ & 8 \\
\hline Significance $^{2}$ & - & - & $* *$ & $* *$ \\
\hline
\end{tabular}

of Encapsulated Shoot Propagules after 6 weeks of Sub-culturing

${ }^{1}$ Bonferroni (Dunn) t Test for paired comparisons

${ }^{2}$ ns, *, ** Non significant, significant at 5 and $1 \%$ level, respectively according to $F$ test 


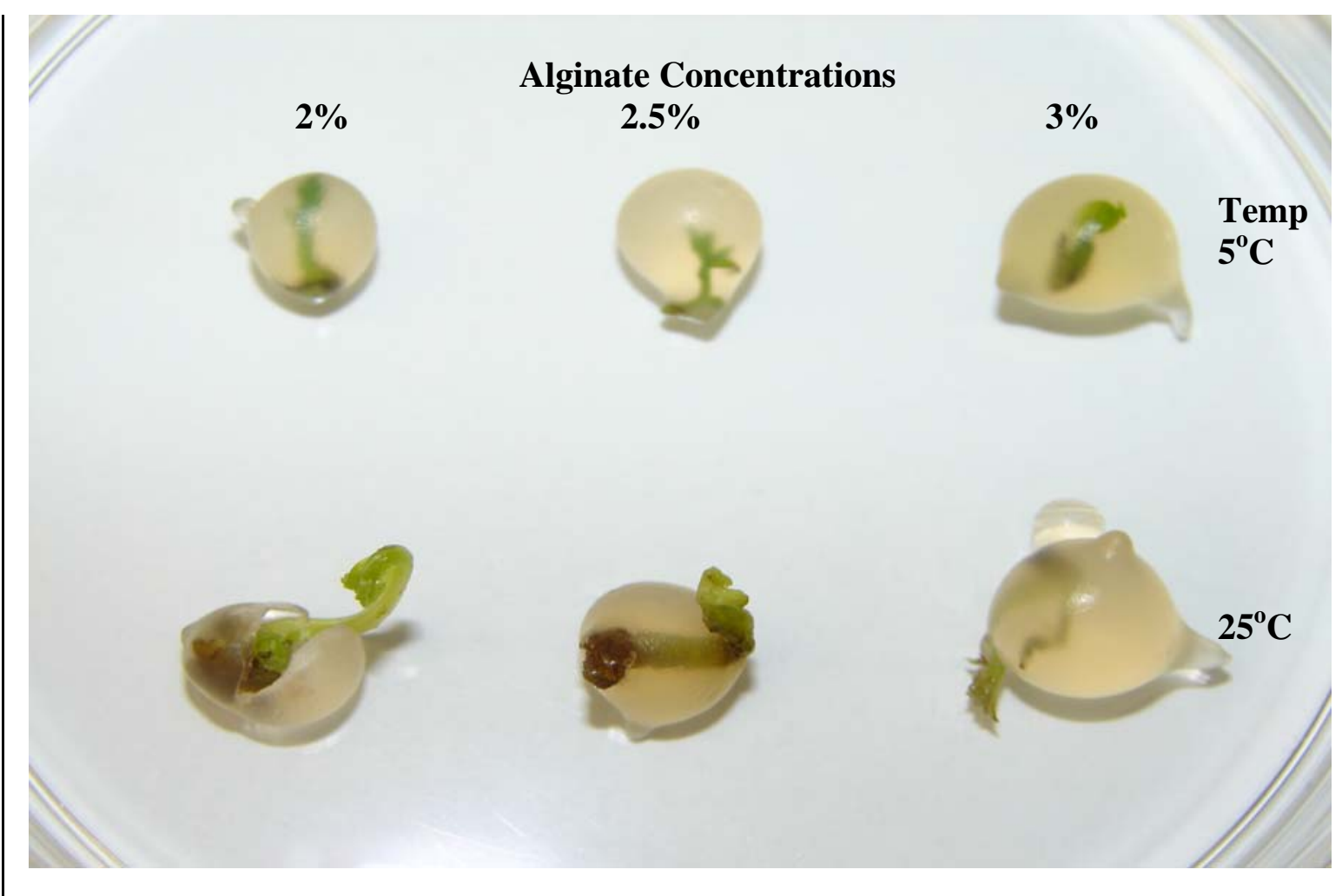

Figure 1: Comparison of encapsulated shoot propagules stored at $5^{\circ} \mathrm{C}$ and $25^{\circ} \mathrm{C}$ for 4 weeks. 
Table 4: Mean Shoot Length and Viability Percentage of Shoot Propagules Stored at Different Temperature and Storage Time Combinations

\begin{tabular}{|c|c|c|c|c|}
\hline $\begin{array}{c}\text { Storage } \\
\text { Temperature } \\
\left({ }^{\circ} \mathrm{C}\right) \\
\end{array}$ & $\begin{array}{l}\text { Storage Time } \\
\text { (Weeks) }\end{array}$ & $\begin{array}{l}\text { Week data } \\
\text { taken }\end{array}$ & $\begin{array}{l}\text { Mean shoot } \\
\text { length }(\mathrm{cm})\end{array}$ & Survival \% \\
\hline \multirow[t]{12}{*}{5} & 4 & 0 & 0.500 & 96 \\
\hline & & 2 & 0.975 & 96 \\
\hline & & 4 & 1.493 & 96 \\
\hline & & 6 & 1.925 & 90 \\
\hline & 8 & 0 & 0.500 & 100 \\
\hline & & 2 & 1.220 & 100 \\
\hline & & 4 & 1.630 & 100 \\
\hline & & 6 & 2.006 & 100 \\
\hline & 12 & 0 & 0.500 & 100 \\
\hline & & 2 & 1.140 & 100 \\
\hline & & 4 & 1.533 & 100 \\
\hline & & 6 & 2.036 & 100 \\
\hline \multirow[t]{12}{*}{25} & 4 & 0 & 1.226 & 100 \\
\hline & & 2 & 1.637 & 96 \\
\hline & & 4 & 1.918 & 53 \\
\hline & & 6 & 2.170 & 33 \\
\hline & 8 & 0 & 1.239 & 76 \\
\hline & & 2 & 1.558 & 40 \\
\hline & & 4 & 1.940 & 16 \\
\hline & & 6 & 2.325 & 13 \\
\hline & 12 & 0 & 0.990 & 33 \\
\hline & & 2 & . & 0 \\
\hline & & 4 & . & 0 \\
\hline & & 6 & . & 0 \\
\hline
\end{tabular}




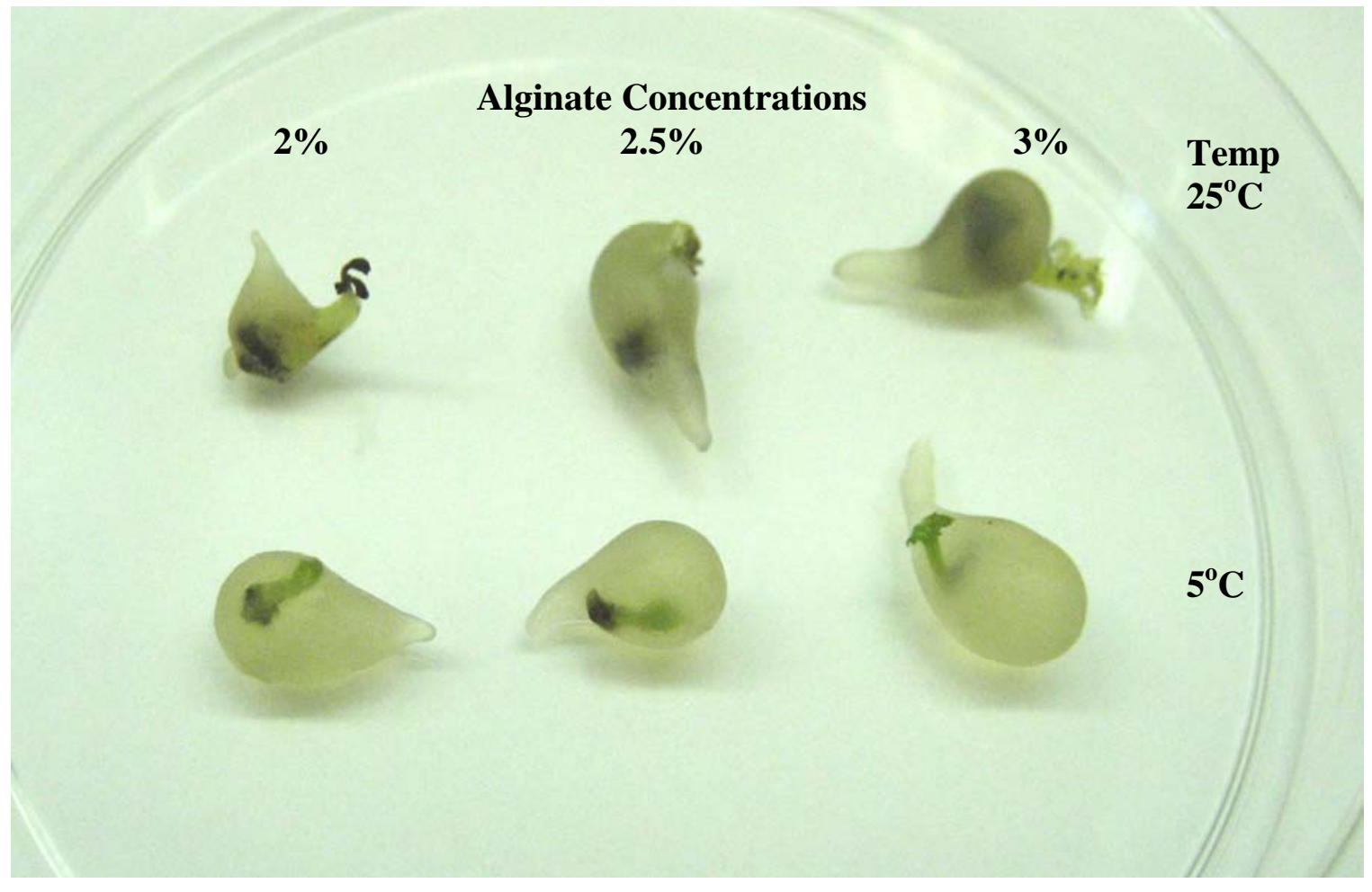

Figure 2: Comparison of solid encapsulated shoot propagules stored at $25^{\circ} \mathrm{C}$ and $5^{\circ} \mathrm{C}$ for 8 weeks. 


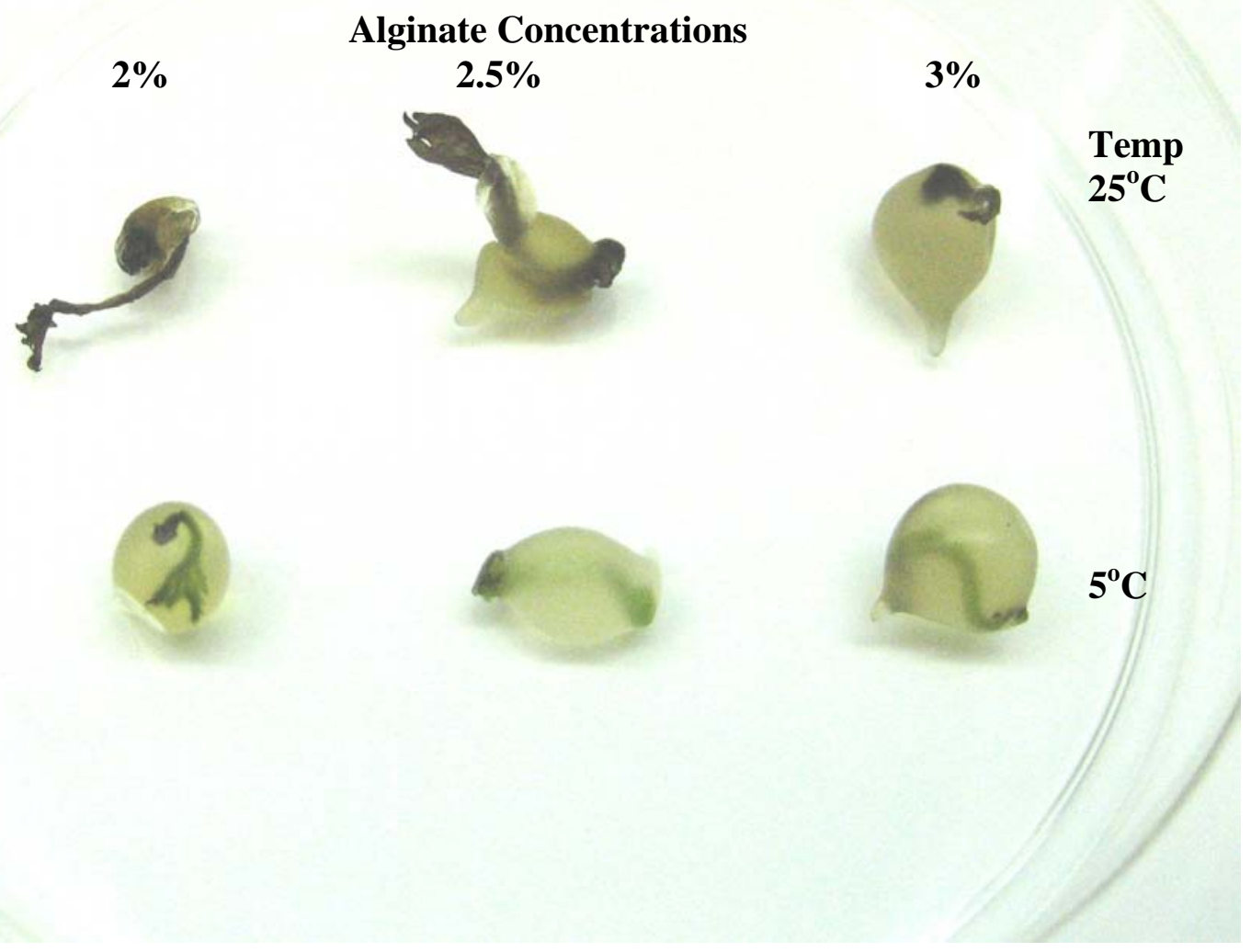

Figure 3: Comparison of solid encapsulated shoot propagules stored at $25^{\circ} \mathrm{C}$ and $5^{\circ} \mathrm{C}$ for 12 weeks. 
length of 4, 8 and 12 week stored beads at 0 weeks sub culturing was 1.22, 1.23 and $0.99 \mathrm{~cm}$ respectively. When these beads re-introduced in-vitro on to the stage II media there was a significant reduction in survival. After 2 weeks of sub culturing $96 \%$ of beads containing shoot propagules that were stored for 4 weeks and $40 \%$ of the 8 week stored beads regenerated with an average shoot length of 1.63, $1.55 \mathrm{~cm}$ respectively. The surviving shoots were unfolding the first leaf at this stage. All the beads that were stored for 12 weeks were necrotic.

By the end of 6 weeks of sub culturing only 33\% of beads containing shoot propagules that were stored for 4 weeks and $13 \%$ of beads that were stored for 8 weeks regenerated with fully unfolded leaves with an average shoot length of 2.17 and $2.32 \mathrm{~cm}$ respectively. Decline in regeneration may have resulted from prolonged shoot growth and nutrient stress while in storage.

The mean shoot length of propagules stored at $25^{\circ} \mathrm{C}$ for 8 and 12 weeks were significantly different and significantly different with shoot propagules stored at $5^{\circ} \mathrm{C}$ for 4, 8 and 12 weeks. There was a significant reduction of viability and mean shoot length of shoot propagules that were stored at $25^{\circ} \mathrm{C}$ for 8 and 12 weeks. Shoot length and viability at each sub culture are shown in data table (Table 4).

Increased shoot mortality was seen with the increased storage time. Pattnaik and Chand (2000) reported that encapsulated auxiliary buds of mulberry stored at $10^{\circ} \mathrm{C}$ for 90 days showed a decline in shoot development. At $25^{\circ} \mathrm{C}$ plants continue the metabolic processes, so the shoot propagules grew out of the beads and produced etiolated shoots as they were stored in dark. Absence of light and depleted levels of $\mathrm{O}_{2}$ might have depressed respiration which might have caused the necrotic or dieback symptoms. At the 
introduction of Stage II conditions ( 0 weeks of sub culturing) they were alive however could not able to recover from the prolonged etiolation and chlorosis. A majority of the shoot propagules that were stored at $25^{\circ} \mathrm{C}$ had blackening of tissue at the base of the shoot where it was in contact with encapsulation material in storage as seen in Figure 4. Reason for this is unknown but may be resulting from the effect of sodium alginate toxicity at $25^{\circ} \mathrm{C}$.

All the encapsulated shoot propagules that were stored at $5^{\circ} \mathrm{C}$ for 4,8 and 12 weeks were survived except one propagule that was stored for 4 weeks period, possibly because of damage during the bead preparation process. No shoot elongation was observed at 0 weeks of sub culturing. Propagules were fully covered and were in the middle of the matrix (Figures 2 and 3.). None of the shoots emerged out of the beads contrasting $100 \%$ emergence of encapsulated shoot propagules that were stored at room temperature. Lower temperatures inhibit the growth of encapsulated propagules; at $4^{\circ} \mathrm{C}$ encapsulated potato shoot tips slowed down the metabolic rates with high viability and long term storability than at $10^{\circ} \mathrm{C}$ (Nyende et al., 2003). When these shoot propagules reintroduced on to the stage II multiplication media all the shoot propagules grown out of beads. At the end of 2 weeks sub culturing there was $96 \%, 100 \%$ and $100 \%$ viability with an average shoot length of $0.97,1.14$ and $1.22 \mathrm{~cm}$ for 4,8 and 12 week stored beads respectively (Table 4). All the beads that were stored for 8 and 12 weeks regenerated at subsequent subculturing developed a single elongated shoot with a fully unfolded leaf by the end of the 6 weeks of sub culturing. Ghosh and Sen (1994) reported only 34\% of regeneration of asparagus somatic embryos that were stored for 90 days. Datta et al., (1999) found no reduction in viability in endangered orchids after 120 days of storage. 

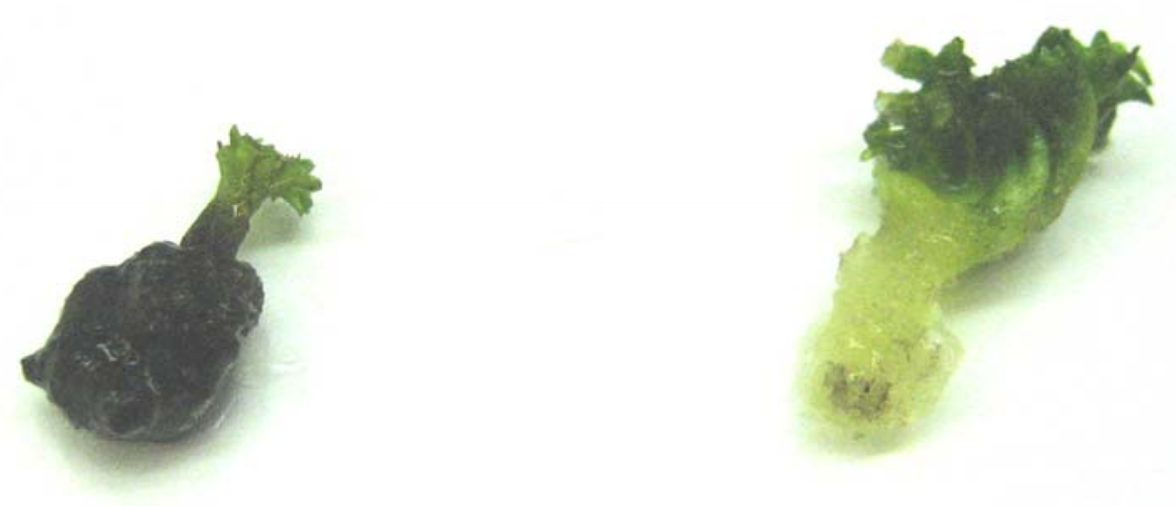

Figure 4: Comparison of encapsulated shoot propagules at 4 weeks of sub culturing that were stored at $5^{\circ} \mathrm{C}$ and $25^{\circ} \mathrm{C}$ for 8 weeks. 
Two shoot propagules that were stored for 4 weeks period were bacterial infected and died at the end of 4 weeks of sub culturing. At the end of 6 weeks of subculturing the viability of 4, 8 and 12 weeks stored beads were 90, 100 and $100 \%$ with an average shoot length of $2.0,2.03,2.17 \mathrm{~cm}$ respectively. All the beads that were stored at $5^{\circ} \mathrm{C}$ regardless of storage period have shown a linear growth of shoot length as seen in Figure 5.

Two shoot propagules one each from 4 and 8 weeks storage produced calli, possibly as a result of the mishandling of propagules while excising from the ex-plant source callus cultures at the time of bead preparation.

Even though alginate concentrations were not significant on mean shoot length and viability, shrinkage of beads were observed. More bead shrinkage was observed at $25^{\circ} \mathrm{C}$ than at $5^{\circ} \mathrm{C}$ and in $2 \%$ alginate concentration than in 2.5 and $3 \%$ concentrations. More shrinkage was observed with the increase in storage period as well. The $2 \%$ alginate concentration beads that were stored for 12 weeks at $25^{\circ} \mathrm{C}$ were observed to have the most shrinkage (Figure 6). Encapsulated propagules that were stored at $5^{\circ} \mathrm{C}$ also showed shrinkage; however this shrinkage did not affect viability or shoot length. Shrinkage of encapsulated propagules and its effect on viability and callus height is unknown.

Conclusion

All the callus propagules and majority of shoot propagules that were stored at $25^{\circ} \mathrm{C}$ were necrotic by the end of 6 weeks of sub culturing. Only $10 \%$ of callus propagules stored at $5^{\circ} \mathrm{C}$ for 4 weeks, produced calli; but no adventitious shoot 


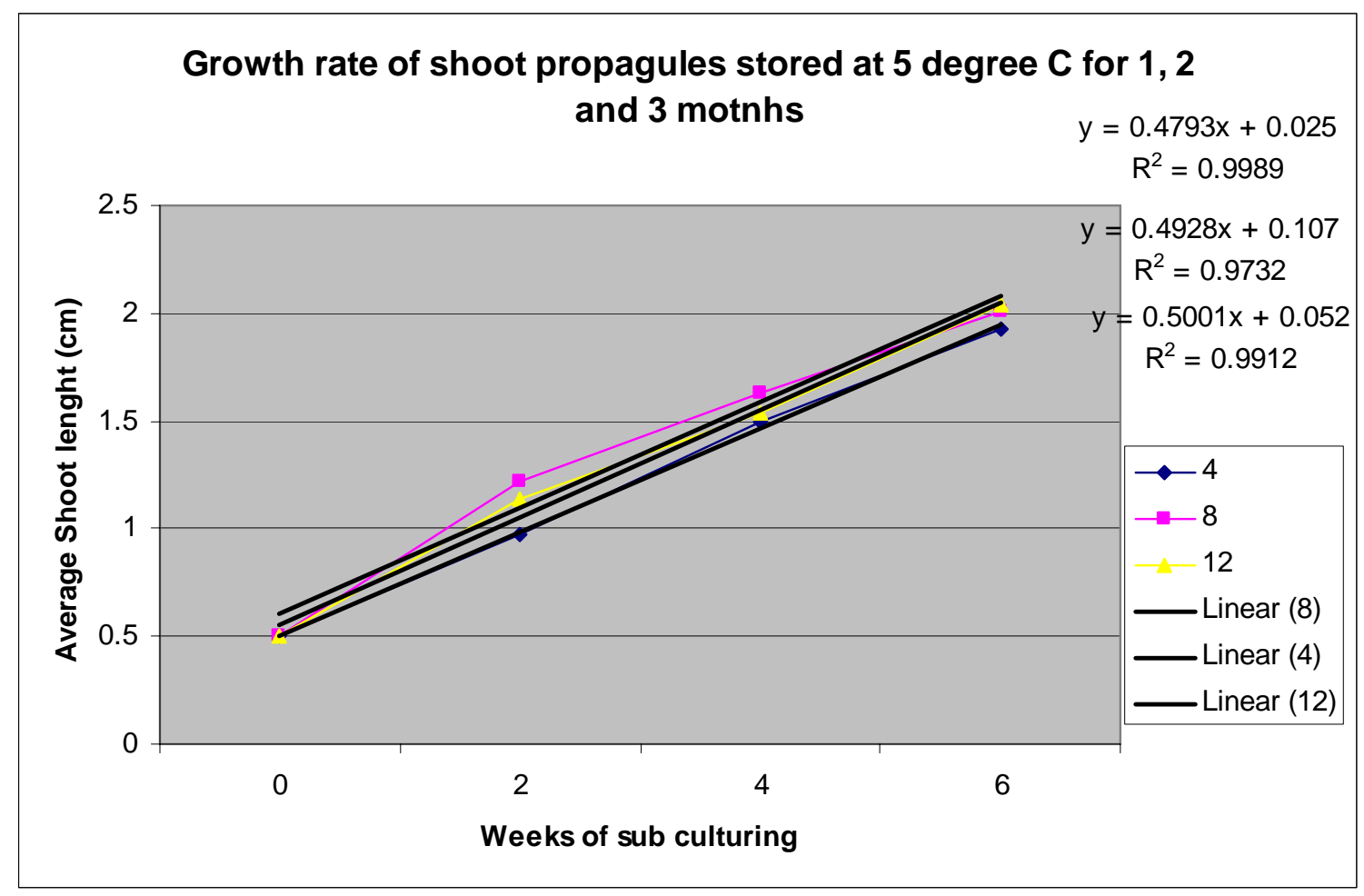

Figure 5: Growth rate of encapsulated shoot propagules stored at $5^{\circ} \mathrm{C}$ for 4,8 and 12 weeks at each sub culturing 


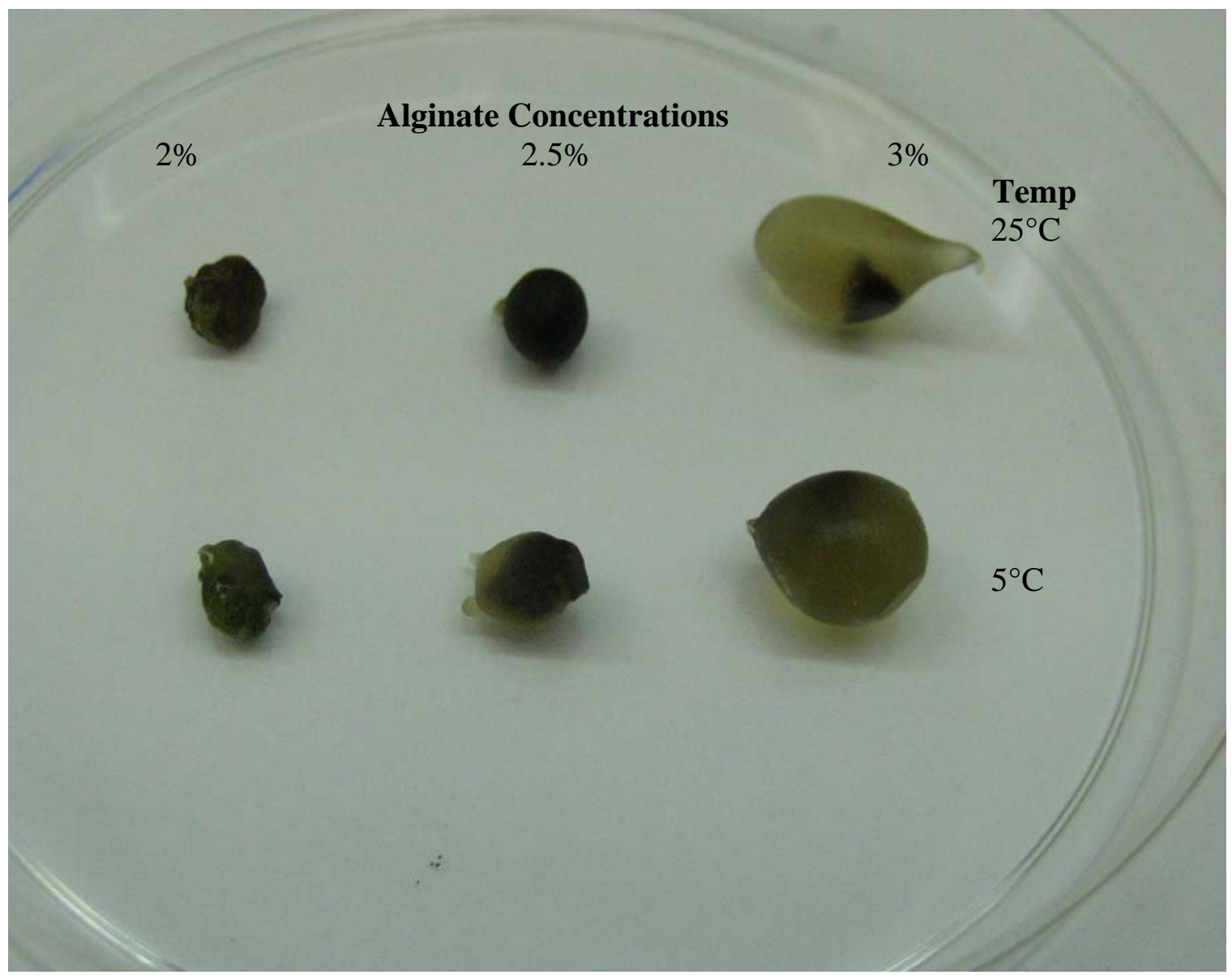

Figure 6: Shrinkage of encapsulated solid beads at $5^{\circ} \mathrm{C}$ and $25^{\circ} \mathrm{C}$ after 12 weeks of storage. 
differentiation was observed. All the shoot propagules survived $5^{\circ} \mathrm{C}$ storage and more than 95\% regeneration observed overall.

These data suggests that the in vitro regeneration of shoot propagules that were stored at $5{ }^{\circ} \mathrm{C}$ was high with high viability percentage and better mean shoot length.

Shoot propagules that were stored at $25^{\circ} \mathrm{C}$ for 4 weeks shown significant shoot length; however viability percentage was greatly reduced by the end of 6 weeks of sub culturing. Therefore it is recommended that the solid bead encapsulation of shoot propagules with $2.75 \%$ alginate concentration and storing beads at $5^{\circ} \mathrm{C}$ increased the success of extended term germplasm storage conservation of Goldenseal.

\section{Hollow Bead Encapsulation and Propagule Regeneration Experiment}

\section{Hollow Bead Encapsulated Callus Propagules}

The entire hollow bead encapsulated callus propagules were dried with necrotic callus propagules by the end of 4 weeks of storage at $25^{\circ} \mathrm{C}$. Lee et al., (2001) reported that the embryonic calli of Daucus carota cultured without nutrient medium turned brown after 3 days and the growth was arrested. At $25^{\circ} \mathrm{C}$, as the metabolic processes continues, calli would have dried and become necrotic because supplemental nutrients in the suspension solution used for hollow bead preparation were not included. No means were compared as all the callus beads were necrotic, and none of them shown regeneration upon reintroduction on to the Stage II media.

All the callus propagules that were stored at $5^{\circ} \mathrm{C}$ for 4 weeks were viable at the introduction to stage II in vitro conditions ( 0 week sub culturing), followed by 80 and $60 \%$ that were stored for 8 and 12 weeks. However none of the calli regenerated and all 
were dried and necrotic by the end of 2 weeks of sub culturing. Encapsulated matrix might not have simulated nutrients as compared to the solid nutrient media which did include supplemental nutrient salts. Breaking the beads and cultivating the propagules directly on the media allow explants to be placed directly on the medium surface allowing supplemental nutrients to be readily available. Cultivating the beads in liquid nutrient media may also give successful regeneration. Patel, et al., (2000) reported 50\% regeneration of callus hollow beads of Solanum tuberosus cultured in liquid MS media. Currently there are no reports on long term storage of calli in calcium alginate hollow beads without supplementing of nutrients.

Leaking of the liquid core from hollow bead was observed at both storage temperatures and was more at room temperature than at $5^{\circ} \mathrm{C}$ (Figure 7). However there was enough solution still left in the bead at $5^{\circ} \mathrm{C}$, to allow propagules to be suspended in the inner cushioning solution. Inner solution leaking increased with increased storage time. Hollow beads stored for 12 weeks had the most leaking of the cushioning solution as compared to 4 and 8 weeks of storage. Leaking of the inner cushioning solution may be related to the thickness of the outer alginate gel matrix. At low concentrations of alginate (0.8\%), the thickness of the outer matrix is reduced. At $25^{\circ} \mathrm{C}$ the inner and outer matrix may less viscous allowing the outer matrix to break open and increasing the leaking of the inner cushioning solution. Effects of the leaking of the inner cushioning solution on shoot length and viability is unknown. Increased calcium concentration levels in the interlocking solution may produce a relatively thicker encapsulation matrix, which may reduce the leakage. However the effect of higher calcium concentration on propagule regeneration has not been reported. 


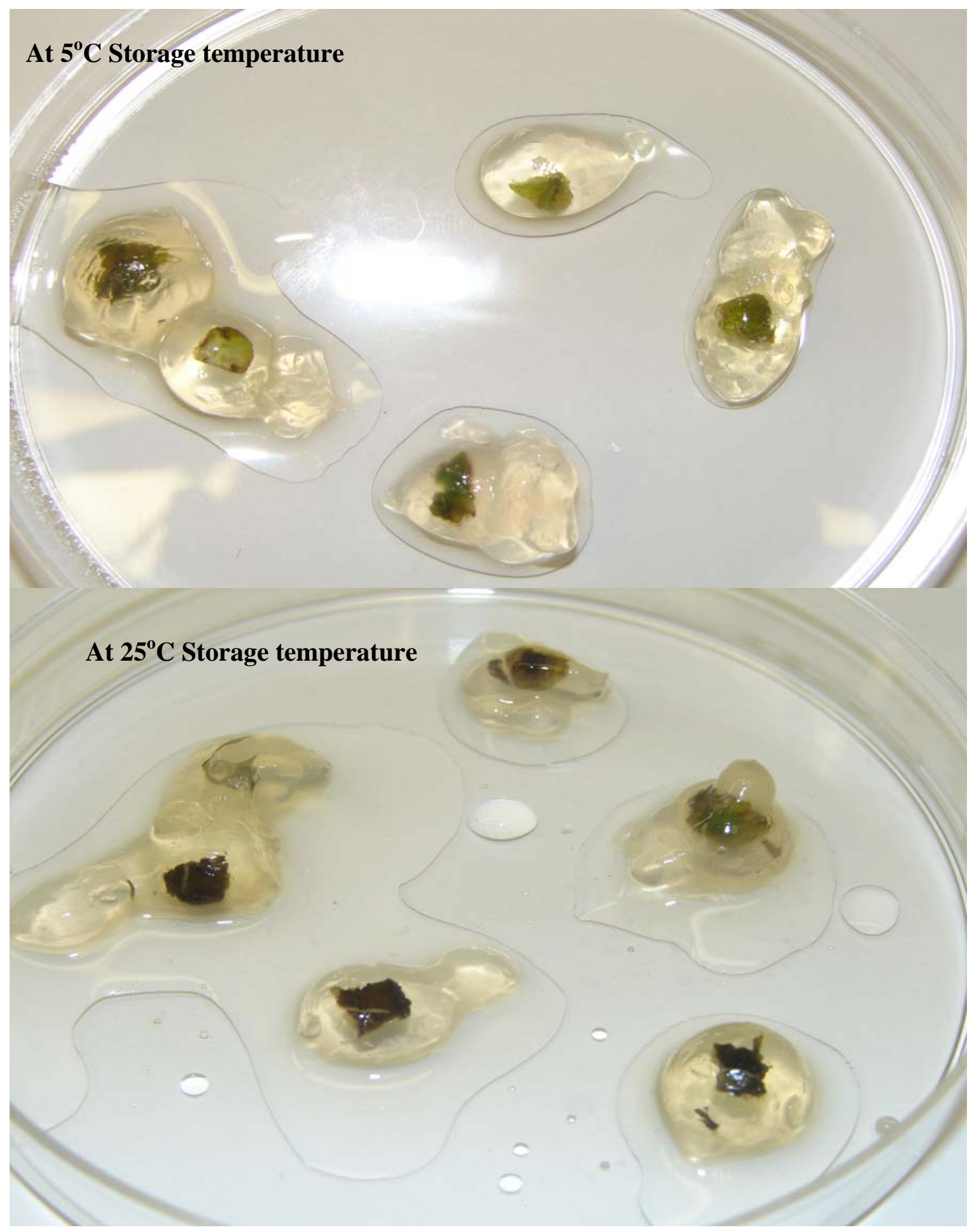

Figure 7: Leaking of inner cushioning solution from hollow beads after 4 week storage at $5^{\circ} \mathrm{C}$ and $25^{\circ} \mathrm{C}$ 
Hollow Bead Encapsulated Shoot Propagules

Storage temperature and storage time had a significant effect on shoot length and viability of shoot propagules (Appendix 5). Mean shoot length of shoot propagules stored at $5^{\circ} \mathrm{C}$ was significantly different with mean shoot length at $25^{\circ} \mathrm{C}$ (Table 5). There was no significant difference in mean shoot lengths of shoot propagules stored for 4 and 8 weeks and both of them significantly differs with mean shoot length of 12 weeks stored propagules. Mean shoot length was less at 12 weeks than at 4, 8 weeks storage. Viability was more $(60 \%)$ at 4 weeks stored beads and declined with the increase of storage time (50\% at 8 weeks and $20 \%$ at 12 weeks) (Appendix 6, Table 5).

None of the hollow bead encapsulated shoot propagules survived by the end of first month of storage. All shoot propagules were dried and necrotic, may be due to lack of nutrients. Nyende, et al., (2003) reported that incubated hollow bead shoot tips of potato in a double concentrated liquid MS medium for 1 hour before storage, showed $100 \%$ regeneration at 4 and $10^{\circ} \mathrm{C}$ for up to 270 days.

All the encapsulated shoot propagules survived 4, 8 and 12 weeks of storage at $5^{\circ} \mathrm{C}$. No shoot growth was measured in any of the storage time treatments. Upon reintroduction of these propagules on to the stage II media, $60 \%$ of propagules that were stored for 4 weeks, $50 \%$ of propagules that were stored for 8 weeks and $20 \%$ of 12 weeks stored propagules produced elongated shoots by the end of 6 weeks of sub culturing with an average shoot length of $1.35,1.14$ and $1.80 \mathrm{~cm}$ respectively. Shoot length and viability percentage of hollow bead encapsulated shoot propagules are shown in Table 6. 
Table 5: Effects of Storage Temperature and Storage Time on Shoot Length and Viability of Hollow Bead Encapsulated Shoot Propagules after 6 Weeks of Subculturing

\begin{tabular}{ccccc}
\hline $\begin{array}{c}\text { Storage } \\
\text { Temperature } \\
\left({ }^{\circ} \mathrm{C}\right)\end{array}$ & $\begin{array}{c}\text { Storage Time } \\
\text { (Weeks) }\end{array}$ & $\begin{array}{c}\text { Number of } \\
\text { Shoot } \\
\text { propagules }\end{array}$ & $\begin{array}{c}\text { Mean Shoot } \\
\text { Length }(\mathrm{cm})\end{array}$ & Survival (\%) \\
\hline 5 & 4 & 40 & $0.64000 \mathrm{~A}$ & 60 \\
& 8 & 40 & $0.51500 \mathrm{~A}$ & 50 \\
& 12 & 40 & $0.39750 \mathrm{~B}$ & 20 \\
25 & 4 & 40 & $0.00000 \mathrm{C}$ & 0 \\
& 8 & 40 & $0.00000 \mathrm{C}$ & 0 \\
& 12 & 40 & $0.00000 \mathrm{C}$ & 0 \\
Significance & - & - & $* *$ & $* *$ \\
\hline
\end{tabular}

${ }^{1}$ Bonferroni (Dunn) t Test for paired comparisons

${ }^{2}$ ns, *, ** Non significant, significant at 5 and $1 \%$ level, respectively according to $F$ test 
Table 6: Mean Shoot Length and Viability Percentage of Hollow Bead Shoot Propagules Stored at $5^{\circ} \mathrm{C}$ and at different storage times.

\begin{tabular}{|c|c|c|c|c|}
\hline $\begin{array}{c}\text { Storage } \\
\text { Temperature } \\
\left({ }^{\circ} \mathrm{C}\right) \\
\end{array}$ & $\begin{array}{l}\text { Storage Time } \\
\text { (Weeks) }\end{array}$ & $\begin{array}{l}\text { Week data } \\
\text { taken }\end{array}$ & $\begin{array}{l}\text { Mean shoot } \\
\text { length }(\mathrm{cm})\end{array}$ & Survival \% \\
\hline \multirow[t]{12}{*}{5} & 4 & 0 & 0.500 & 60 \\
\hline & & 2 & 0.611 & 60 \\
\hline & & 4 & 1.000 & 60 \\
\hline & & 6 & 1.350 & 60 \\
\hline & 8 & 0 & 0.500 & 50 \\
\hline & & 2 & 0.612 & 50 \\
\hline & & 4 & 0.833 & 50 \\
\hline & & 6 & 1.140 & 50 \\
\hline & 12 & 0 & 0.500 & 20 \\
\hline & & 2 & 0.700 & 20 \\
\hline & & 4 & 1.550 & 20 \\
\hline & & 6 & 1.800 & 20 \\
\hline
\end{tabular}


Conclusion

All the encapsulated callus and shoot propagules stored at $25^{\circ} \mathrm{C}$ were necrotic by the end of storage period. At $5^{\circ} \mathrm{C}$ both the shoot and callus propagules shown high viability percentage by the end of storage. However none of the callus propagules regenerated on stage II media, only shoot propagules started regenerating. By the end of 6 weeks of sub culturing 60,50 and $20 \%$ of beads that were stored for 4, 8 and 12 weeks respectively were grown in to fully developed plantlets. These data suggests that the shoot propagules of goldenseal (Hydrastis canadensis) can also be stored in calcium alginate hollow beads at $5^{\circ} \mathrm{C}$, however regeneration decline as storage time increases. 


\section{Conclusions and Suggestions}

Synthetic seeds do not accumulate storage nutrients like natural seeds, and are prone to drying and can be stored only for a limited period. The synthetic seeds require supplemental nutrients for normal plant growth and development. They emerge out of the encapsulation capsule and develop into new plantlets, a process that can be slowed down by decreasing storage temperatures.

At $25^{\circ} \mathrm{C}$ all the hollow beads and majority of the solid beads were necrotic, as the plants continued growth in dark with reduced supplemental nutrients. Callus propagules were more necrotic than shoot propagules. Few shoot propagules emerged out of the encapsulation capsule and produced etiolated shoots, and were not able to regenerate into whole plants when transferred on to the Stage II medium. This inability to regenerate may be a result from prolonged etiolation and chlorosis.

At $5^{\circ} \mathrm{C}$ there was high viability of encapsulated propagules after cold storage (0 weeks sub culturing). Shoot propagules had the highest regeneration rate upon reintroduction on to the Stage II media as compared to callus propagules. Some callus propagules had growth at early stages of in vitro re-introduction; however they were not able to emerge through the encapsulation capsule. Depletion of supplemental nutrient salts and shear forces of high viscosity alginate matrix on the propagules may be the reasons for emergence failure. Rupturing the beads or excising the propagules from the bead prior to transferring onto the media, may increase viability and regeneration, as the nutrients are readily available and shear forces of encapsulated matrix are eliminated.

Viability and regeneration of shoot propagules were less in hollow beads as there were no supplemental nutrients added in the encapsulation material. Leaking of 
cushioning solutions was observed in hollow beads at both temperatures, more at $25^{\circ} \mathrm{C}$ than at $5^{\circ} \mathrm{C}$. One reason for the leaking of the cushioning solution may be a result from the thickness of the gel matrix and concentration gradient between the inner and outer atmospheres. Further research on thickness of calcium alginate matrix, concentration of cushioning solution and the effect of leaking on propagule regeneration needs to be conducted.

Encapsulation protocols for long term conservation of Goldenseal germplasm in this research have begun to be developed. High viability (93-100\%) and high regeneration (93-100\%) of solid encapsulated shoot propagules imply that the Goldenseal shoot propagules can be stored in sodium alginate solid beads at $5^{\circ} \mathrm{C}$ for longer periods. This indicates that the shoot propagules have potential to be supplemental germplasm sources along with seed and root cuttings.

Alginate encapsulation may also have applications for reducing somaclonal variations in continuous in vitro cultivating germplasm systems. Alginate encapsulated propagules can also be easily transported aseptically; and can be useful in the commercial markets for synthetic seed production for cultivating clonal populations of Goldenseal, as the demand for the species increases. Apart from germplasm conservation, short term storage of encapsulated propagules would allow for increased numbers of clonal population of synseeds to be produced for direct planting applications. 


\section{Literature Cited}

Ballester A., Janeiro, L.V., and A.M. Vietez. 1997. Cold storage of shoot cultures and alginate encapsulation of shoot tips of Camellia japonica L. and Camellia reticulate Lindley. Sci. Hort. 71: 67-78

Bannerman, J. 1997. Goldenseal in World trade: Pressures and Potentials, Herbal gram, 41, 51-52

Bapat, V.A., and P.S. Rao. 1990. In vivo growth of encapsulated axillary buds of mulberry (Morus indica L.). Plant Cell, Tissue and Organ Culture 20:69-70

Bedir E., Lata H., Schaenburg B., and R.M. Moraes. 2004. International Society for Horticulture Sciences; In vitro Plant Regeneration from Leaf derived Callus in Goldenseal. ACTA Hort. 629, ISHS 2004

Castillo B., Smith M.A.L., and U.L. Yadava. 1998. Plant regeneration from encapsulated somatic embryos of Carica papaya L. Plant Cell Reports 17:172-176.

Chapman V.J. and D.J. Chapman. 1980. Seaweeds and their uses, (3rd ed). Chapman and Hall, London.

Chun-Zhao L., Murch S. J., Jain J.C., and P.K. Saxena. 2003. Goldenseal (Hydrastis canadensis): In vitro regeneration for germplasm conservation and elimination of heavy metal contamination; In vitro Cellular and Developmental Biology, Vol 40:pp 75-79.

Collin H.A., and S. Edwards. 1998. Plant cell culture. Springer-Verlag, New York, NY

Davis, J.M., and J.A. McCoy. 2000. NC State University; Commercial Goldenseal Cultivation, Horticulture Information Leaflets

Datta, K. B., Kanjilal, B., Sarkar, D., 1999. Artificial seed technology. Development of a protocol in Geodorum densiflorum (Lam) Schltr. An endangered orchid. Curr.

Sci. 76:1142-1145.

Faster, S. 1991, Goldenseal Hydrastis Canadensis, Botanical Series No 309, American Botonical Council, Austin, Texas

Ganpathi, T. R., Suprasanna, P., Bapat, V.A., and P.S. Rao. 1992. Propagation of Banana through encapsulated shoot tips, Plant Cell Rep.11: 571-575

Gardi, T., Piccoini, E., and A. Standardi. 1999. Effect of bead nutrient composition on regrowth of stored vitro-derived encapsulated microcutting of different woody species, J. Microencapsul. 16:13 -25 
Ghosh, B. and S. Sen. 1994. Plant regeneration from alginate encapsulated somatic embryos of Asparagus cooperi Baker. Plant Cell Reports 13: 381-385.

Grieve, M. 1995. Botanical.com, A Modern Herbal, at http://www.botanical.com/botanical/mgmh/g/goldensea27.html

Hall C.K. and N.D. Camper. 2002. Tissue culture of Goldenseal (Hydrastis Canadensis L), In Vitro Dev. Biol.-Plant. 38:293-295, May-June 2002

Hamrick J. L., W.Godt M. J., and L.S. Sherman-Broyles. 2004. Factors influencing levels of genetic diversity in woody plant species, New Forests.

Hartmann H.T., Kester D.E., Davies, Jr. F.T., and R.L. Geneve. 2002. Plant propagation: principles and practices (7th ed.). Upper Saddle River, NJ.

Kyte, L., and J. Kleyn. 1996. Plants from test tubes: An introduction to micropropagation (3rd ed). Portland, OR.

Lee E.K., Cho D.Y., and W.H. Soh. 2001. Enhanced production and germination of somatic embryos by temporary starvation in tissue cultures of Daucus carota.

Mix-Wagner, G., Schumacher, H.M., R.J. Cross. 2003. Recovery of potato apices after several years of storage in liquid nitrogen, Cryoletters. Vol. 24, No. 1, pp 33-41.

Nyende, A.B., Schittenhelm S., Mix-Wagner G., and Greef J. 2003. Production, Storability and Regeneration of shoot tips of Potato (Solanum Tuberosum L.) Encapsulated in Calcium Alginate Hollow Beads. In Vitro Cell. Dev. Biol.-Plant 39:540-544.

Oldfield, M.L. 1984. The value of Conserving genetic resources, Gene resource Conservation: A Socioeconomic Necessity ; U.S Department of Interior National Park Service, Washington D C.

Patel A.V., Pusch I., Mix-Wagner G., and K.D. Vorlop 2000. A novel encapsulation technique for the production of artificial seeds; Springer-Verlag 2000 ; Plant Cell Reports (2000) 19:868-874.

Pattnaik, A. V., Chand, P. K. 2000, Morphogenic response of the alginate encapsulated acillary buds from in vitro shoot cultures of six mulberries. Plant cell Tiss. Organ Cult. 60:177-185.

Piccioni, E., and A. Standardi. 1995. Encapsulation of micropropagated buds of six woody species. Plant Cell, Tissue and Organ Culture 42:221-226.

Predny M.L., and J.L. Chamberlain. 2005, Goldenseal (Hydrastis canadensis); An Annotated Bibliography, Gen. Tech. Rep, USDA, SRS - 88. Ashville, NC. 
Redenbaugh, K., Slade, D., Viss, P. and Fujji, J.A. 1987; Encapsulation of somatic embryos in synthetic seed coats. HortScience 22(5): 803-809.

SAS9.1.3®, 2003. SAS Institute, North Carolina, USA.

Scowcroft, W.R. and Larkin, P.J., 1981. Somaclonal variation - A novel source of variability from cell cultures for plant improvement. Theoretical and Applied Genetics 60: 197-214.

Standardi, A., and Piccioni, E. 1998. Recent perspectives on synthetic seed technology using non-embryogenic in vitro-derived explants. Int. J. Plant Sci. 159(6):968978.

Steel, R.G.D and Torrie, J.H. 1980. Principles and procedures of Statistics. A Biometrical Approach (II edition). McGraw-Hill. New York.

Suzane Sanders (n.d); Does Breeding System Contribute to Rarity of Goldenseal (Hydrastis Canadensis), The American Midland Naturalist; Vol 152 Number 1 (Jul 2004).

Timbert, R., Barbotin, J.N., Thomas, D. 1996. Enhancing carrot somatic embryos survival during slow dehydration, by encapsulation and control of dehydration. Plant Sci120: 215-222.

West T P., Ravindra M.B.,and Preece J.E. (2006); Encapsulation, storage and growth of Hibiscus moscheutos nodal segments, Plant Cell Tissue and Organ Culture;87:223-231. 


\section{APPENDIX}

Appendix Table 1: Effect of storage temperature, storage time and alginate concentration on callus size of calcium alginate encapsulated callus propagules

Variable: Callus Size

Source of Variation

Run

Storage Temperature (ST)

Storage Period (SP)

Alginate Concentration (AC)

ST*SP

$\mathrm{ST}^{*} \mathrm{AC}$

$\mathrm{SP} * \mathrm{AC}$

$\mathrm{ST} * \mathrm{SP} * \mathrm{AC}$

Error

df

MS

0.007

0.972

1.062

0.042

0.246

0.050

0.044

0.074

0.012

ns, *, ** not significant, significant at the $5 \%$ and $1 \%$ levels respectively. 
Appendix Table 2: Effect of storage temperature, storage time and alginate concentration on viability of calcium alginate encapsulated callus propagules

Variable: Viability

$\begin{array}{lllll}\text { Source of Variation } & \text { df } & \text { MS } & \text { F } & \text { Significance }\end{array}$

Run

Storage Temperature (ST)

Storage Period (SP)

Alginate Concentration (AC)

ST*SP

$\mathrm{ST} * \mathrm{AC}$

$\mathrm{SP} * \mathrm{AC}$

$1 \quad 0.001 \quad 0.02 \quad$ ns

$1 \quad 7.001 \quad 82.05 \quad * *$

$2 \quad 8.984 \quad 105.29 \quad * *$

$2 \quad 0.293 \quad 3.43 \quad *$

$2 \quad 1.751 \quad 20.52 \quad * *$

$2 \quad 0.418 \quad 4.90 \quad * *$

$\mathrm{ST} * \mathrm{SP} * \mathrm{AC}$

$4 \quad 0.545 \quad 6.39 \quad * *$

$\begin{array}{llll}12 & 0.634 & 7.44 & * *\end{array}$

Error $698 \quad 0.085$

ns, *, ** not significant, significant at the $5 \%$ and $1 \%$ levels respectively 
Appendix Table 3: Effect of storage temperature, storage time and alginate concentration on shoot length of calcium alginate encapsulated shoot propagules

Variable: Shoot Length

Source of Variation

Run

Storage Temperature (ST)

Storage Period (SP)

Alginate Concentration (AC)

$\mathrm{ST} * \mathrm{SP}$

$\mathrm{ST}^{*} \mathrm{SP} * \mathrm{AC}$

Error

ns, *, ** not significant, significant at the $5 \%$ and $1 \%$ levels respectively
MS

F

0.031

18.611

2.557

0.095

4.438

0.068

0.079
Significance

ns

**

$* *$

nS

**

ns

0.87 ns


Appendix Table 4: Effect of storage temperature, storage time and alginate concentration on viability of calcium alginate encapsulated shoot propagules

Variable: Viability

Source of Variation

Run

Storage Temperature (ST)

Storage Period (SP)

Alginate Concentration (AC)

$\mathrm{ST} * \mathrm{SP}$

$\mathrm{ST}^{*} \mathrm{SP} * \mathrm{AC}$

Error

ns, *, ** not significant, significant at the $5 \%$ and $1 \%$ levels respectively
MS $\quad$ F $\quad$ Significance

$\begin{array}{lll}0.034 & 0.41 \quad \text { ns }\end{array}$

$63.012 \quad 743.48 \quad * *$

$4.968 \quad 58.62 \quad * *$

$0.184 \quad 2.18$ ns

$6.862 \quad 80.97 \quad * *$

$\begin{array}{lll}0.118 & 1.42 \quad \mathrm{~ns}\end{array}$

0.084 
Appendix Table 5: Effect of storage temperature, storage time and alginate concentration on shoot length of calcium alginate hollow bead encapsulated shoot propagules

Variable: Shoot Length

$\begin{array}{llllll}\text { Source of Variation } & \text { df } & \text { MS } & \text { F } & \text { Significance }\end{array}$

Run

10.007

$\begin{array}{ll}1 & 4.529 \\ 2 & 0.084\end{array}$

0.28

ns

Storage Temperature (ST)

173.97

3.26

ST*SP

2

0.084

3.26

**

*

*

Error

233

0.026

ns, *, ** not significant, significant at the $5 \%$ and $1 \%$ levels respectively. 
Appendix Table 6: Effect of storage temperature, storage time and alginate concentration on viability of calcium alginate encapsulated shoot propagules

Variable: Viability

Source of Variation

Run

Storage Temperature (ST)

Storage Period (SP)

$\mathrm{ST} * \mathrm{SP}$

$$
\text { df }
$$

MS

$\mathbf{F}$

0.037

27.337

0.487

0.487

0.104

Error

233

ns, *, ** not significant, significant at the $5 \%$ and $1 \%$ levels respectively

$\begin{array}{rl}0.36 & \mathrm{~ns} \\ 261.72 & * * \\ 4.67 & * * \\ 4.67 & * *\end{array}$

ns

$* *$

$* *$ 